\title{
Anaconda-becoming: Huni Kuin image-songs, an Amerindian relational aesthetics
}

Devir-anaconda: huni kuin cantos-imagem, uma estética relacional ameríndia

\author{
Els Lagrou * \\ *Universidade Federal do Rio de Janeiro - Rio de Janeiro, RJ, Brazil \\ elagrou1963@gmail.com
}




\begin{abstract}
After depicting the contemporary scene of Huni Kuin ayahuasca shamanism and artistic agency, I analyze a selection of image-songs from this ritual. The songs unveil the workings of embodied perception and synesthesia, that is, the transductions of bodily sensations and perceptions in vision, rhythm, song and sound. The experience entails a process of other-becoming where to know means to see through the eyes of Other; to be covered with the skin/ornaments of those beings one has consumed and to sing through their voice. This other-becoming is a becoming in a deleuzian sense, which means that the lived experience is situated in-between the space of self and other. In this context the expression "you are what you eat" has specific implications for one's health and for the acquisition of agentive and perceptive capabilities of other beings. The ritual technique of almost becoming consists of alternatingly producing and undoing temporary transformations through song.
\end{abstract}

Keywords: shamanism; ayahuasca; Amerindian relational aesthetics; song.

\title{
Resumo
}

Depois de apresentar a cena contemporânea da agencia artística e do xamanismo ayahuasqueiro dos Huni Kuin, apresento uma seleção de seus cantos-imagem. Os cantos revelam a lógica de uma percepção incorporada e sinestésica, isto é, as transduções de sensações corporais e percepções entre visão, ritmo, canto e som. A experiência veicula um processo de tornar-se outro onde conhecer significa olhar através dos olhos de Outro; estar coberto com a pele/ornamentos dos seres que se consumiu e cantar através de sua voz. Este devir-Outro é um devir deleuziano porque a experiência vivida se situa no espaço entre eu e outro. Nesse contexto a expressão "você é o que come" tem implicações específicas para o bem-estar e para a aquisição de capacidades agentivas e perceptivas de outros seres. A técnica ritual desse quase devir consiste em, de modo alternado, produzir e desfazer transformações temporárias através do canto.

Palavras-chave: xamanismo; ayahuasca; estética relacional ameríndia; canto. 


\section{Pano and Huni Kuin shamanism from invisibility to super-visibility}

My interest in perception, visual phenomena, shamanism, and ritual brought me, almost thirty years ago, to the Huni Kuin of the Purus River, a native people of the Brazilian/Peruvian Amazonian rainforest. ${ }^{1}$ There I have been, from the very start, fascinated by the intriguing relationship of mutual implication between image and sound in the shamanistic experience of the Huni Kuin with nixi pae. Thus my initial interest in patterned and agentive visual images on bodies, artifacts and visions, brought me to sound images and the lines of rhythm and song. The mutual implication of song lines and lines of sight and flight is one of the leading topics of this text. ${ }^{2}$

Let me briefly situate this potent agent to which Michael Taussig has dedicated some very beautiful pages at the intersection of indigenous and riverine shamanism, at the cross-roads of thought systems that intermingle and contaminate each other in very ingenious and poetic ways (Taussig, 1993, 2011, 2015). The brew is at the origin of a local Peruvian riverine and Amazonian healing system called Vegetalismo (Luna, 1986). As shown by Luna (1986) and Gow (1994) for the Peruvian Amazon and Taussig for the Columbian highlands and forests, the expansion of ayahuasca shamanism, a name of Quechua origin meaning "vine of the souls", is closely related to the growth of a mestizo riverine population influenced by diverse indigenous traditions, although a shamanic interethnic tradition existed long before the arrival of Colonialism in the region. ${ }^{3}$ Ayahuasca or yagé shamanism seems to be particularly suited

1 I have been working with the Huni Kuin/Cashinahua of the Upper Purus River since 1989. I initiated the analysis and translation of huni meka songs with the renowned specialist Leoncio Domingos Huni Kuin, previous head of the Peruvian village of Conta, in 2006. Since 2014 I have been working with the brothers Sebirua Antonio Napoleão Bardales Huni Kuin and Txana Xane Francisco Napoleão Bardales Huni Kuin, ritual specialists of the newly founded village Txana Mudu on the Alto Purus River.

2 Because of lack of space it will be impossible to display all the materials that sustain the argument. I recommend readers to read also Lagrou (2013b, 2018). A version of this article has been presented at the Centre of Ethnomusicology of the University of Columbia, New York, on the 28th of April 2016. I thank Ana Ochoa and her colleagues and students for the invitation and the stimulating ensuing discussion.

3 See Gil (2006); Chaumeil (1991); Langdon (1991, 2012). 
for the practice of Amerindian cosmopolitics, ${ }^{4}$ from the Shipibo shamans of the Ucayali to the Taitas of the Putumayo and the Huni Kuin of the Jordão river.

The use of this vision-inducing brew is widespread in the whole region of the Northwestern Amazon, especially among indigenous peoples but also among river dwellers and the local population in general. Yagé in Colombia, ayahuasca in Peru, the brew is called cipó (which translates as vine) or Daime in Brazil. In Colombia and Peru the use of the brew is mediated by and associated with indigenous shamanistic traditions, while in Brazil, in the beginning of the twentieth Century, several religions arose around the ingestion of the vine, such as the Christian/Gnostic inspired Santo Daime, the Afro-Brazilian and Amazonian Barquinha with its emphasis on the dance of the encantados and the União do Vegetal, a group that cultivates a more intellectual esoteric tradition. ${ }^{5}$

More recently, ayahuasca has been at the epicenter of a growing international movement of Urban, Neo or New Shamanism, a psychedelic wave building on experiences initiated by the hippies in the sixties and related to ideals of self-discovery and healing disseminated by the New Age movement. A vast bibliography has been produced on the urban use of ayahuasca, by far overshadowing the literature on its use by Native Amerindian people. ${ }^{6}$ This new shamanism is a powerful force behind political alliances between indigenous leaders and environmentally engaged metropolitan national and international associations and individuals.

Pano speaking people (Shipibo, Huni Kuin and Yawanawa) have been protagonists in this ever expanding shamanistic movement and their role can be partially explained by their remarkable openness and capacity of articulation with the outside world through shamanistic rituals and artistic exchange that characterizes their cosmopolitics. ${ }^{7}$ In Brazil, there have been, from the start,

4 Cosmopolitics is a term coined by Stengers (1997) and first used in the field of Amerindian ontologies by Sztutman (2012) to refer to shamanism as a cosmopolitical, relational field. Shamanistic rituals are political events where relations amongst humans and between humans and non human beings are negotiated.

5 For a systematization of the vast literature on these ayahuasca churches see Labate, Rose and Santos (2009).

6 For a permanent update of events related to the topic see http://bialabate.net. See also Labate, Rose and Santos (2009); Labate, Cavnar and Gearin (2017) among others.

7 See Belaunde (2016) for the Peruvian Amazon. 
strong links between the Santo Daime church and Huni Kuin families. Mestre Irineu, the founding father of Santo Daime, and his followers were rubber tappers, migrants mostly from the Northeastern region of Brazil, and the use of ayahuasca was transmitted to them by the indigenous peoples of the region, such as the Huni Kuin from the Jordão, Envira and Taraucá rivers and by mestizos, who were all involved in rubber tapping. ${ }^{8}$

During the last decade, in Brazil, several eminent Huni Kuin families from the Jordão River have been especially successful in the weaving of an extended web of "guardians of the forest" over Europe, the United States and the biggest metropolises of Brazil. The movement has also links with the peyote cult and the Red Path (caminho vermelho) in Mexico and the United States, as well as with the recent use of ayahuasca in medical circles, frequently related to the ayahuasqueiro churches. An interesting chapter of this shamanistic revival has been the incorporation of ayahuasca by indigenous peoples who traditionally didn't use vision-inducing substances other than tobacco, such as the Guarani communities in the South ${ }^{9}$ and, recently, the Tupi speaking Yudja from the Xingu region. Not only Huni Kuin specialists, but also Ashaninka and Yawanawa shamans are renowned and much respected for their ritual song and performance. Among the Yudja the recent initiation into the use of ayahuasca has had a decisive impact on the revival of their shamanistic practices (Stolze Lima, personal communication).

The Pano groups involved in this movement have combined their shamanistic activities with a remarkable artistic expansion. The Shipibo-Conibo and Arawakan Piro from Peru share with the Huni Kuin the auto-denomination of "people with design". ${ }^{10}$ Design (kene) covering the bodies of certain beings, humans, animals, plants and artifacts, points towards their relatedness

8 Deshayes (2006) suggests that the name Daime derives from dami, one of the names given to the brew by several Pano speaking people, such as the Yaminaua. In all these related languages, as well as in Cashinahua, dami means transformation, figure and visionary experience (Lagrou, 2007). The Daimistas themselves, on the other hand, are said to translate the origin of the term as derived from a prayer: "give me" (dai-me).

9 Langdon and Rose (2010).

10 The Marubo, although not involved in the global movement of shamanistic expansion, share with their Pano relatives the quality of being "people with design" and of relating this characteristic to their relatedness with spirit beings (Cesarino, 2011). For the importance of design in visionary experience for the Sharanahua see Déléage (2009); for the Piro see Gow (2001). 
and transformational capability, revealing the eminently shamanistic property of patterned design. ${ }^{11}$

Recently, the MAHKU collective of artists, founded in 2011 in the Rio Jordão and coordinated by Ibã Isaias Sales Huni Kuin, a master of huni meka chants, has gained international visibility. Most of the dami (figurative) paintings of the group refer to the ayahuasca songs taught by Ibã to his pupils, who then paint them under his supervision. This project was conceived during a course, at the Federal University of Acre, Forest Campus, in 2009, by Amilton Mattos, who accompanies MAHKU since its foundation. The short impressive career of the MAHKU collective is illustrative of its potential for dialogue with other artistic traditions and media (Mattos; Ibã, 2017). In 2011 a blog (www.nixi-pae.blogspot. com.br) was created which rendered the group an invitation of the Fondation Cartier in Paris to participate of the Exhibition Histoires de voir (2012). For this exhibition, a video was made to show the creative process involved in the production of the paintings. Some of the artists of MAHKU participated also in the MIRA show of Contemporary indigenous art of Latin America in Belo Horizonte (2013), a historical milestone in the history of recognition of indigenous art in Brazil. MAHKU was also present at the exhibition at the Tomie Ohtake Institute, Histórias mestiças, in 2014, in dialogue with the installation by internationally renowned artist Ernesto Neto. In 2015 and 2016 the collective collaborated with the Franco-Belgian artist Naziha Mestaoui for the installation "Sounds of Light" at Matarazzo, São Paulo.

New shamanism is an interesting site to observe, not only the potential of connection, but also the role of equivocation ${ }^{12}$ and the avoidance of verbal communication in guaranteeing ritual efficacy. ${ }^{13}$ As has been shown by Losonczy and Mesturini (2010) for yagé rituals administered by taitas in Colombia

11 For the Huni Kuin see Lagrou (2007, 2011, 2013a); Keifenheim (1999); Shipibo: Roe (1982); Gebhart-Sayer (1986); Illius (1987); Belaunde (2012); Piro: Gow (2001); Sharanahua: Déléage (2009); Marubo: Cesarino (2011); Yawanawa: Reis (2015).

12 See Viveiros de Castro (2004) on the importance of recognizing equivocation as method of inquiry for the anthropological endeavor.

13 With respect to the avoidance of speech in interethnic ayahuasca rituals it is noteworthy that the Peruvian icaros of Shipibo origin, used by riverine vegetalistas (Luna, 1986), as well as the humming of Colombian yagé specialists, are characterized by their ethnographers as almost "wordless singing", humming, where it is the melody and rhythm that becomes transformed into images more than the words (Taussig, 2011, 2015). 
and abroad, shamans and public do not necessarily share the same ontological presuppositions with respect to the phenomenological reality experienced in their visions. Ritual efficacy depends on the capability of the shaman to avoid dialogue in order to let the ritual work. An analysis by Coutinho of the nixi pae rituals administered by the young Huni Kuin shaman Txana Bane and his carioca wife, a Jungian psychologist, during the first decade of 2000 in Rio de Janeiro, pointed in the same direction. Ritual efficacy depended on Bane singing the right songs in his native tongue to help clear the visions of his clients, while the talking was done by his wife, who translated the visionary experience in terms of an ontology of the collective unconscious and feelings of togetherness she shared with the public, composed mostly of students in psychology (Coutinho, 2016). Efforts at translating the songs were undertaken, where the pragmatic context of their new setting was as important as the original meaning.

Another important figure for the expansion of ayahuasca shamanism was Agostinho Manduca Inka Mudu, who, after a life as a rubber tapper and travelling from one river to another, started to study plant medicine and huni meka songs. In his newly founded village on the Jordão River, surrounded by his kin, he organized a medicine garden and ayahuasca sessions for visitors from abroad and became well known among his urban followers and extended family as a powerful pajé (shaman). ${ }^{14}$ Agostinho had a dream of publishing his book on plants and contacted for this purpose several institutions. The Federal University of Minas Gerais published the first book (Manduca, 2012), composed of a CD, short contextualizing texts in Portuguese, and narratives by specialists about plant medicine in their native language, accompanied by dami drawings. A second project was produced in collaboration with the Botanical Garden of Rio de Janeiro. The book of healing from the Jordão River (Manduca; Quinet, 2014) is the first to present a botanical identification.

It was in the context of the publication of this book that Ernesto Neto was introduced to the Huni Kuin and to ayahuasca. From this moment on, very much impressed by the potency of the visionary experience and of the rituals

14 Pajé is the Portuguese word for shaman, derived from the Tupi language. Lately, with the expansion of urban shamanism and its association with ambientalism, the appellation pajé has come to signify a broader spectrum of knowledgeable ritual leaders and herbalists (Conklin, 2002). For a description of the movement around Agostinho see Castor (2012). 
guided by them, Neto has exposed installations at international shows with the presence of the brew and of the Huni Kuin. Thus his installation at Tomie Ohtake was prepared for the performance of a nixi pae ritual by the Huni Kuin inside the museum and exposed a recipient with ayahuasca in its center. Neto, who for years has been producing organic penetrable large-scale sensual sculptures, which he calls body/spaces with strong uterine and/or organic connotations, "naked body-concepts with skin-psyche-sex", inserts in his organic/ cosmic space the nixi pae beverage. After the Tomie Othake show other installations/performances, some of them with the ritual use of ayahuasca administered by the Huni Kuin to a restricted public were performed at the Arp Museum in Köln (Neto, 2014), the Guggenheim museum of Bilbao (2014), the TBA21 of Vienna (2015), the Kiasma museum of contemporary art in Helsinki (2016) and the Venice Biennale (2017). Currently Neto is working at a giant installation of GaiaMotherTree for the Zurich Main Station where he plans to take the "spirit of the forest" together with the Huni Kuin to the center of Zurich. ${ }^{15}$

The three young shamans leading the international nixi pae movement are sons of Siã Sales Huni Kuin, all in their twenties. Agostinho was also a close relative of Siã and member of the ASKARJ, the association of Cashinahua rubber tappers from the Jordão, presided by Siã. Siã, in his early fifties, is an important leader of the Jordão region, son of Sueiro Sales Huni Kuin, leader of the first indigenous land to be emancipated in the seventies from the regime of aviamento, the well known system of forced indebtedness imposed by the rubber bosses implemented in the region around the turning of the previous Century. ${ }^{16}$

When I arrived for the first time in Rio Branco, capital of the State of Acre, in 1989, on my way to the Huni Kuin on the Purus River, at the frontier with Peru, "The First Encounter of the peoples of the forest" was being held. This Encounter was held a year after the killing by big landowners of the syndical

15 The affinity of Neto's personal cosmology with that of the Huni Kuin is a topic I intend to explore more properly in another article. Interviews are being conducted with the artist since 2014. A first approach of the encounter between Neto and the Huni Kuin is proposed in Goldstein and Labate (2017).

16 See Aquino and Iglesias (1994). As is well known to specialists, the economy of rubber extraction in the Amazonian rainforest was characterized by extreme violence in the three countries rich in rubber, Peru, Colombia and Brazil. See Taussig (1986). 
leader of the rubber tappers, Chico Mendes. It was a big political event with the presence of environmentalists from all over the country and from abroad. Marina Silva (2002) was also present, at the time a young woman who grew up in the forest in a family of rubber tappers and whose husband had Huni Kuin origins. Marina was to become presidential candidate of the green party in the last Brazilian elections. This encounter set the model for the joint political efforts of indigenous peoples and local settlers living of the sustainable extraction of forest products. In this sense, Acre has a special meaning to the green movement in Brazil.

Being the most numerous indigenous group of Acre, with over 8,000 people, and another 2,000 living in Peru, the Huni Kuin, along with the Pianko family of the Ashaninka, played an important role in this alliance. At that time, in the late eighties, the family of Siã and their allies (such as Marina Silva and local anthropologist Terri Aquino, who assisted indigenous leaders in their legal fight against the rubber bosses) used to frequent Santo Daime. Ten years later, the people of the Jordão substituted the influence of Daime in their rituals at home by giving priority to their own nixi pae songs, in native language.

At the beginning of the twentieth Century, the Huni Kuin dispersed and fled to several rivers after they took revenge on their rubber boss at the Envira River, killing him and his family. One group travelled as far as the headwaters of the Curanja River in Peru, where they lived their life far away from direct contact with the nonindigenous population of the region until the late forties. ${ }^{17}$ Since the seventies many families of those who had fled to the headwaters in Peru crossed the Brazilian border to settle back in Brazil, mostly on the Purus River. These are the people I work with. These people have been capable of maintaining community life and the chain of transmission of ritual knowledge without interruption, while the groups who stayed in Brazil were obliged to live shattered in small settlements, following the logic of rubber extraction. It is interesting to note, however, that those who live in the much more isolated regions of Peru and Brazil, on the Purus and Curanja rivers, and are considered by their kin to be authorities with respect to ritual knowledge and weaving techniques, have undergone a massive conversion to evangelism over the last

17 Montag (2002); Kensinger (1995); McCallum (2002); Aquino and Iglesias (1994). 
fifteen years, while the people of the Jordão and other rivers in the region are experiencing a strong revival of their shamanism.

If in the nineties shamanism was visibly strong but carefully kept as invisible as possible, especially in the Purus area, what we see today in regions inhabited by Huni Kuin who are ex-rubber tappers and maintain strong relations with local cities and the capital of the State, is the production of a ritual culture of super visibility of shamanistic practices and attire.

American protestant missionaries of the Summer Institute of Linguistics have been with the Peruvian Huni Kuin since early contact on the Curanja river in the fifties and Protestantism, in the form of readings of the bible translated in their native tongue, was present during the nineties when I lived among them. But only a minority of the village used to attend these ceremonies organized by the local native pastor, while their own rituals were held normally. Great was therefore my surprise with the situation I encountered in 2014 after a long period of absence. Now only two of the thirty-six Huni Kuin villages, spread along the Alto Purus River in Brazil, resist conversion to evangelism. ${ }^{18}$

\section{Ritual song, Txana Mudu and the revival of shamanism on the Purus River}

It is in one of these villages, called Txana Mudu, that live the two brothers, Sebirua and Txana Xane with whom I have been working on the translation of the songs of nixi pae. One a shaman in becoming, the other a specialist in ritual song, they left Peru to flee and counteract the influence of evangelism. What they found at the Brazilian side, however, was a situation not very different from the one they lived in Peru, only more recently installed.

To make strong again "the thinking bodies" of their kin, to teach the young men of the village, their students, to think of their bodies-selves - nukun yuda

18 Zezinho Yube, a young filmmaker of the Tarauacá region, explored this paradox in his film Kene yuxi, as voltas do kene (2010). Upon a journey in search of women's knowledge of traditional design on the Purus River, he encountered kin people with a greater knowledge of traditional songs and design patterns than in the places he and his parents came from, while at the same time noting a massive adhesion of these people to evangelic cult practices that devalue traditional rituals. 
xinankin -, the two brothers founded a village where no evangelical preacher is allowed to settle in. ${ }^{19}$ "To strengthen one's thinking body" is one of the principle motivations to partake in the ritual of nixi pae, accompanied by the tobacco snuff, dume. To make strong and clear one's body, to become conscious of the complex agentive web of doubles and entities, yuxin beings, that act within and around one's body, trying to capture one's soul and cover it with another body, it is necessary to take nixi pae, the vine that makes you see what is normally invisible.

Sebirua explains that all nixi pae rituals follow the same basic sequence of songs: first come the "calling songs", then come the "normalizing or stabilizing songs", followed by the "songs to see" and, finally, the "songs to sent away". ${ }^{20}$ This structure, however, seems to work following a fractal logic, since the whole sequence of calling and undoing is present in every single song, be it one to call, see, stabilize or sent away. As soon as the effects of the brew make themselves felt through a mixture of feelings of shivering, cold, apprehension or fear and/ or excitement, accelerated heart beat, the hearing of ruffling sounds like rushing water and the appearing of the first visual effects of rotating or serpentine patterns of design before the closed eyes of those who consumed the brew, one has to sing a "calling song". Those who know how to sing start to call huni, the vision itself, and the people of nixi pae, spirit yuxin beings. ${ }^{21}$

19 The concept $y u d a$, translated as body, refers to the human living, sentient being. The term nukun yuda, our body, is also used to refer to the collectivity or community of people living together in a same village, sharing food and other substances, turning them into a body of a kind. Spirit or yuxin only exists as such when temporarily or definitively separated from the body.

20 See also Ibã (2006). In this essay Ibã transcribes in native language several nixi pae songs he learned from his elders. In the presentation of the songs in Portuguese he specifies if the song serves to call the force of the vision-inducing agent, to heal dizziness or take away its effects. The songs are not translated. Actually Ibã is working at the publication of his huni meka to be published.

21 To learn to sing in ayahuasca rituals is one of the ways to be initiated into shamanism. Among the Pano people (Shipibo, Yawanawa, Huni Kuin, Yaminahua and Sharanahua) to become specialized in the use of ayahuasca was a road open to all men. Women would partake less frequently, but the participation in nixi pae rituals or initiation into shamanism was not at all prohibited. Difficult to combine with child rearing, some women would participate only after menopause, others would take protective measures (Colpron, 2004; Gil, 2006; Keifenheim, 2002; Reis, 2015). Few Huni Kuin women in the Purus area admit at taking nixi pae, while each time more women drink and sing at the Tarauacá, Jordão and Envira rivers. Among their traditional neighbors, the Ashaninka (Acre), women partake and sing on equal foot with men at the ayahuasca rituals. 
A calling song is always followed by a "normalizing" or "stabilizing song" that intends to tame the excess of visionary effects. The sensory effects of the drug are described as multi-sensorial: the experience is essentially synesthetic: sounds translate into images, as do smells. If sound and image are too frightening, one can rub a sweet smelling leaf, such as bedudu (called alfavaca or palo santo), under the nose of the one suffering. The person can also sniff tobacco powder to alleviate or make the vision clear, but the only way to really interfere with the visionary experience is to be able to sing the right song: the "songs to normalize" or, in the end, the proper songs "to sent away".

In bodily terms, it is considered good to throw up when the agency of the brew inside one's body becomes too strong and makes the body shiver in nausea. Among indigenous peoples of the region, induced throwing up is a regularly used cleansing technique to make the body resistant, to take away feelings of heaviness and laziness and to expel powerful substances whose agency inside the body needs to be controlled or counteracted. Big amounts of manioc or corn brew are ingested to help people cleanse the body thoroughly in the nixpu pima initiation and katxanawa fertility rituals and the same logic holds for nixi pae.22 Instead of ingesting a small concentrated amount of the brew, as the Ashaninka, their neighbors, do, the Huni Kuin prepare big watery amounts of the brew to facilitate the cleansing effect of throwing up. When throwing up the excess of nixi pae, one expels also agentive substances imbued with yuxin agency that may be causing harm inside the body and in the parallel world of doubles, where they hold the person's eye soul. Body and soul are not at all separated here, since substances are vehicles of yuxin agency.

The third kind of songs, "songs to see", is an important group of songs. As the Huni Kuin frequently explained to me, the principle reason one takes nixi pae is "to see". It is in this sense that nixi pae is an eminently cosmopolitical enterprise. Nixi pae reveals the hidden reality of the agency of nonhumans who have the power to cause pain, illness and dead. The plants and animals eaten that have owners or doubles who take revenge, kupin, have their proper song

22 During the nixpu pima ritual this vomiting is provoked by kampun. At the end of this rite of passage for girls and boys, the children receive their first application of kampun. Kampun is a toad poison, used by several Panoan groups in the region, that is applied on the burned skin. For an overview of the recent history of the use of kampun beyond the indigenous context see Carneiro da Cunha (2009). For the Huni Kuin see Lagrou (2007). 
to be sung during the ritual. The song makes the hunter see what the doubles, the yuxin of the animals ingested, are doing with his eye soul, causing his body to feel headaches, fatigue or worse. These are clear cases of predator/prey reversal (see Lagrou, 2013b, 2018).

But illness can have other causes too. A shaman can take nixi pae to discover if and who put a spell dau/feitiço on a sick person. The patient is painted with red achiote paint to protect and perfume him/herself, and sits next to the shaman who blows tobacco over his head and gives him or her a small amount of the brew in order to be able to see the patient in visions. The feitiço frequently takes the form of a poisonous leaf that, once discovered by the shaman in his vision, will be expelled by the patient after taking big amounts of manioc brew, sometimes with the help of the application on the skin of the emetic frog poison kampun.

Another important cosmopolitical aspect of nixi pae rituals is the invitation of visitors to partake in the ritual. This is considered a strategy to unveil the intentions of strangers, indigenous and nonindigenous. The Huni Kuin share this policy with their Pano neighbors (Calavia, 2006; Déléage, 2009; Gil, 2006). One can take nixi pae in contexts of detention with allies, as well as in contexts of tension before taking important decisions. Thus nixi pae gatherings, while kept away from the eyes of foreign missionaries, became an important activity to accompany political meetings in the region.

Those who know how to take nixi pae and how to sing powerfully in a process of becoming Yube, the spirit of the anaconda water snake, become strong and angry and can be dangerous for potential enemies. Therefore to take nixi pae with strangers is a challenge, since you do not know, beforehand, the power of the song of Yube shamans. One needs a huinti kuxi, a heart that is not easily frightened, to resist fear once one is under the effect of the ingested agency and hears the voice of Yube coming out of the mouth of one's rival. It is in this sense that sorcery can be used in nixi pae. The singer can throw a spell on his rival and put him to run. Nixi pae is therefore a perfect setting to mutually test the influence and charisma of strong shamans and to fight out political conflicts around trust and treachery.

My friends from the Purus, recently arrived from Peru, travelled to visit their relatives who live at the Tarauacá River. There they took nixi pae with a shaman of the region. The shaman, envious of the knowledge of ritual song 
displayed by the brothers, put a spell on one of them during the session itself. Sebirua run off into the forest and stayed there for three days and three nights. All this time, running through the forest, he saw the shaman. Finally he met a boa constrictor, Yube, who helped him to get out of that in which the shaman had trapped him. This is a shaman known to everyone, stressed my friend. People come from far away to see him. He combines techniques from different sources. To practice sorcery, for instance, he uses black candles.

As I have shown elsewhere (Lagrou, 2018), the initiation in singing implies a process of other-becoming. Because the powerful singer has become Yube, the ancestor and spirit owner of the anacondas, his sweat is dangerous for his own kin, especially for his wife and children who could become ill if he touched them without taking a bath after the ritual. The agonistic side of the ritual is responsible for the fact that nixi pae is mostly taken by young hunters accompanied by older shamans who have already mastered Yube's voice and song. When they sing, it is Yube, a multiplicity of Yube, who sing through/with him in a frightening sound that evokes mimetically all the beings and sounds of the forest. Yube is the predator par excellence and when he comes, it is to devour all those he encounters on his path.

This is how Sebirua found his first master who taught him the right songs when he was a teenager living in Peru:

"You take nixi pae? And how do you sing to take away the drunkenness?" (asked the master) "I don't know." "Ah! But nobody takes it without knowing how to sing!" And he sang. Afterwards he charged. He said: "Another day I will sing for real, but now you give me a battery." He charged. This way I learned this song. When I took (nixi pae) and sang it, from the sky came that scintillating thing, really from the vision itself. Thus it is a beautiful and strong vision that comes. Each time it comes. If you are not strong enough to endure it, you don't finish this song. You have to endure to sing it the whole way through. To call the mirror, scintillating things; to call the force of these brilliant things from the sky, the stars. It sings the strings of cotton of different colors: it starts with white, red, blue and yellow, until it finishes with black: this force arrives. It speaks of the rainbow. The colors it is speaking out are from the rainbow. This is a song about how to open the vision (bepen bidãkatsi). The vine will turn around the mirror of vision for us to see. (Sebirua, 2015). 


\section{Song of the mirror of the sky}

Nai beisitimen, nai beisitimen

Betxa sanã beimen,

betxa sanã beimen

He, He, He, He. Terãtin, terãtin, terãtin

$\mathrm{He}$ ! He! He!

Nai beisitimen, nai beisitimen

Betxa sanã beimen,

betxda sanã beimen

$\mathrm{He}, \mathrm{He}, \mathrm{He}$, He, terãtin, terãtin, terãtin

Nai basa maxedi, nai basa masheri

hawen paxin kewai,

hawen paxin kewai

paxin kewã rãtia, paxin kewã rãtia

$\mathrm{He}$, He, He, He, terãtin terãtin terãtin

Duxau yuxibu,

duxau yuxibu

Duxau yuxibu

hawen kuka yunua,

hawen kuka yunua

kuka iki betsai,

kuka iki betsaii

he he he he terãtin, terãtin, terãtin

shãka huni ãwãibu,

shãka huni ãwãinbu

shãka huni ãwãinbu,

shãka huni ãwãinbu

shãka aketanime

shãka aka tanimen
Mirror of the sky? Mirror of the sky?

Is your light coming in my direction;

Your light coming in my direction?

He! He! He! ${ }^{23}$ (The light) encircling us

He! He! He!

Mirror of the sky? Mirror of the sky?

Is your light coming in my direction?

Your light coming in my direction?

He! He! He! (The light) encircling us

The red achiote of yellow monkey of the sky ${ }^{24}$ his yellow fringe hanging down,

his yellow fringe hanging down, he has a yellow fringe, a yellow fringe

He! He! He! (The light) encircling us

The ancestor of the bird duxau,

the ancestor of the bird duxau

The ancestor of the bird duxau

His father-in-law sent him,

his father in law sent him

His calling kuka! (father in law) became

different, his calling kuka! became different

He! He! He! (The light) encircling us

the women of the vine of lightness,

the women of the vine of lightness

the women of the vine of lightness,

the women of the vine of lightness

we are becoming light,

we are becoming light,

23 He!: is the male answer to a call.

24 This monkey is a nisun. When you sing nixi pae you have to sing this nisun that stays inside our body. 
keya keya tanimen, keya keya tanimen shãka huni ãwãinbu, shãka huni ãwãinbu shãka huni ayanai, shãka huni ayanai ayanain kuimen, ayanain kuimen he, he, he, he, terãtin terãtin terãtin

uke nai yukea, uke nai yukea nai kubu runtiki, nai kubu duntuntiki hushu yumen mepuen, huxu yumen mepuen hanu meriskitani, hanu mediskitani pae meriskitani, pae mediskitani... slowly going up, slowly going up the women of the vine of lightness, the women of the vine of lightness drinking the vine of lightness, drinking the vine of lightness are we drinking the real one? Are we drinking the real one? He! He! He! (The light) encircling us (we) are up there in the middle of the sky, up there in the middle of the sky at the tip of the trunk of the sky the white cotton thread hanging down, the white cotton thread hanging down there it is loosening, there it is loosening loosening the pressure of the vine, loosening the pressure of the vine...

This is an extract of one of the calling songs, a song the brothers chose to record when visiting us in Rio. The song invokes the myth xanka huni, "huni of lightness", the story of the people who, before taking the vine, poured the brew at the edges of the village. They then drank the vine and with a lot of music and noise started to float and slowly to rise. Thus the whole village went up to the sky. These are the people of the vine, the people of huni. Only one person stayed behind, the ancestor of the bird duxau. His father-in-law had sent him off to warn the people of the other village to come with them. But instead of bringing the message, the boy first made love to a girl of the other village. When he finally arrived with the people of the other village, it was too late. The people of xanka huni were already too high to reach. His cry, - duxau!-, transformed him into the bird who bears the name of the sound he made at the moment he tried to join his kin.

The song mobilizes yet another mythical theme. That of Yube, the incestuous brother who, after having been discovered by his sister by the mark 
of genipa she painted on his face, became the moon. It is the head, chopped off by enemies, that will become the moon and to get up in the sky, he asks his mother for cotton strings of different colors to hang from the pole of the sky and climb up. This is the rainbow, also called the path of the dead, or Yube's blood. In this song the strings to reconnect those on earth with those living in the sky are thrown by the women of the vine of lightness.

Songs are always referred to a source. Human teachers, specialists, teach almost all of the songs a huni shaman knows. In the case quoted above, the shaman was not Sebirua's father or father-in-law, or someone close with whom he lived, and therefore he asked for a retribution to teach him his song. The Huni Kuin say the old ones, men and women alike, who have a lot of knowledge, used to be stingy with the transmission of their knowledge. The insistence on the fact that this was much more the case in the past than now is revealing, because I heard this comment always in the context of complaints about the unwillingness of masters today to share their knowledge of song and weaving with people eager to learn. The initiative, insistence and desire to learn must come from the one who wants to learn. This is the idea behind the affirmation of stinginess on the part of the unanya, "those who know". The disciple has to go after the master and the master will test his desire and his strength. The learning process also requires physical endurance and the preparation of the body. More so, it implies a process of consubstancialization with the master, of transmission of substances, vehicles of thought.

The chain of transmission of song knowledge is a topic of debate between the generations. With the imposition, by differentiated school programs, of the principle that all knowledge should be public and sharable, an equivocation arises with respect to the chain of transmission of knowledge considered proper to a Huni Kuin way of live. And the fact that most songs and myths remain without translation in their publications has certainly something to do with it.

Knowledge about nixi pae is ancestral in a way that is important for future generations; the songs allow a lived exploration of the connectedness of beings and their successive processes of transformation. The elders refrain from sharing their knowledge with distant kin that don't care for them. They complain about the fact that not following the right procedures of learning is conducing to the impoverishment and loss of depth of the learning process. 
Public policies with respect to the patrimonialization of indigenous knowledge need not only to take into account the content of the knowledge transmitted, but more importantly the logic of transmission, the generative context of actualization of a relational theory of knowledge (Carneiro da Cunha, 2009; Gallois, 2012).

Thus every song is attributed to an identified source, to the person, alive or deceased, who thought the song. And more, when you sing, it is this dead person who sings through you:

To endure it is good to sing. Each one is going to sing his song; the song of the singer. Inside of the vine you will be a nixi pae singer; nixi pae yuã meni, someone who knows. In the vision that you sing, it isn't you who is singing; what comes out is the voice of the person that died a long time ago and used to take nixi pae. It is his voice that will come out. The voice that came out is the voice of that person that used to take the vine. (Sebirua, 2014).

Most of the songs actualize a long chain of transmission, from father or grand-father to son, or son-in-law and so on. Most songs are considered to go back to the ancestor himself, the first human to have known nixi pae when living among the anaconda people, who in turn learned the songs from them. This ancestor is called Dua Busen who became transformed in Yube, anaconda. Some versions of the myth call him only by the name Yube.

A summary of the founding myth, based on a version told by Txana and Sebirua, goes as follows: When hunting, Dua Busen saw something strange happening. He saw some animals walking around wearing earrings. Then he saw an anaconda woman coming out of the lake. She was covered in design and beautiful. Tapir had called her, throwing genipa fruits in the lake. After tapir made love to anaconda woman she went back into the lake. A few days later, unable to forget, Busen goes back, throws the genipa fruits in the water, and the snake woman appears. He jumps on her, thus frightening her. The anaconda woman transforms into an anaconda and wraps herself around him, threatening him with her tongue in his face. Now he is afraid of being eaten and begs her to come back to her human form. She agrees and makes him explain his intentions. He promises to accompany her to the lake. They make love and, before she takes him on her back to jump into the lake, 
she uses a "perspectival leaf" to change his perception. ${ }^{25}$ Underwater he sees the anaconda people as people.

He marries her and they have children. Then comes the day the anaconda people drink nixi pae. His wife warns him not to partake in the ritual, but he insists. When he starts to feel the effect of the brew, a frightening sensation, his vision changes: he sees his in-laws as anacondas and screams in panic. His wife calls her father to sing for him, but he continues screaming. The next day nobody wants to talk to him anymore. He so seriously offended his in-laws that he has to flee in order not to be killed. He goes back to his human wife and has another child. When looking for genipap to paint his newborn human child, he steps with his feet in a river and the anacondas, his snake children and wife, get him. They break his bones, but do not swallow him. He is saved by his kin but knows he will soon die.

The night before he dies he teaches his people how to find and prepare nixi pae. He sings the whole night and dies the next day. From his body will grow the vine and the chacruna leave, used together to prepare the brew. The myth ends with the comment that only a small boy, Nambua, who did not drink, but stayed awake the whole night listening, learned the songs of Yube. This is how his knowledge started to be transmitted. Nambua is frequently invoked in ritual song, when Yube addresses him as "my adoptive son".

Many nixi pae songs refer to parts of this founding myth. In fact, to take the brew and experience its visions means to actualize, to live again, the experience of the ancestor: the ancestor-becoming being a Yube-becoming. The myth explains the complex identity of Yube and of the substance of the vine. The vine is called the blood or urine of Yube and can be considered to be both the substance of Yube the anaconda people, and Yube, the ancestor who became Yube. The experience of other-becoming is an ancestor-becoming, but it is a becoming ancestor that had already traced the path of other-becoming. Yube is a name that connects several kinds and levels of being(s). Yube is the ancestor who became the moon. Yube is how one calls the shaman, specialist

25 The use of leaves that change a person's perception has been noted among several Pano speaking groups, among the Huni Kuin (Lagrou, 2007); Shipibo (Gebhart-Sayer, 1986); among the Saharanahua (Déléage, 2009). 
in the nixi pae ritual, as well as the ancestor of all anacondas, Yube Xeni, the old huge anaconda, the most powerful of all spirit beings. Yube hi is the ritual name given to the lupuna tree, xunu, called the tree of life, the tree of Yube, where the souls and different kinds of yuxibu live. This aspect of Yube, as that which connects and transforms into different beings, had not escaped my attention. I had written about it (Lagrou, 2007), but was worried I might have somehow forced the chain of analogies too much, maybe going further than my Huni Kuin teachers would have gone.

It was therefore a gratifying surprise to hear the explanation by Sebirua and Txana of the name they chose for their longhouse-university, a center for the study of things Huni Kuin, in the village they founded on the Purus river. Yubenibu tananai refers to the fact that all phenomena that bear the name Yube are connected and that to understand this means to learn the right path of thought to be followed, for women as well as for men. The first song Sebirua and Txana chose to record in a studio in Rio was a song dedicated to their village. Different in melody from all other songs I have heard, Sebirua did not learn this song from a master; he received it from the people of huni themselves in a vision.

\section{Blowing a prayer}

$\begin{array}{ll}\text { Haux, haux, haux } & \text { Haux, haux, haux } \\ \text { mia xeatan ikin } & \text { You will be swallowed } \\ \text { eskawãtiki bakebu } & \text { Thus we do, my sons } \\ \text { matun ixunun ninkaki pewaxun } & \text { I will make you think well with my song } \\ \text { matun mae anu } & \text { when you drink, think about your work in } \\ \text { beya xarabu } & \text { the village; about our festivities } \\ \text { nukun dayaxadabu } & \text { Our different kinds of work } \\ \text { ninkake pewakina } & \text { Think about them to make them good } \\ \text { haux, haux, haux } & \text { haux, haux, haux } \\ \text { Haux, haux, haux } & \text { haux, haux, haux } \\ \text { Haux, haux, haux } & \text { haux, haux, haux }\end{array}$


Sebirua explains:

This is an incantation to ask for strength and good things to arrive in vision. You need to blow this prayer over the brew before you consume nixi pae, as well as before inhaling tobacco powder, dume. First I address the vine: I will drink you. Then I address my sons, the people of the village: I will sing the dewe of the vine for you to listen/understand (ninka) well. (2014).

\section{Opening song of Yubenibu tanani}

This is the song of our own village, in order to see the village, if we are living well, to examine the learning process of our traditional school Yubenibu tanani. When I took the vine, he showed me everything. From there I took (extracted) this song for my sons.

Since we are nearby the Madiha, who live around us, one has to extract their voice, but with the words of the Huni Kuin. All their songs are like this, as I hear whenever I go to visit them. Because this is the difference of my village with respect to the others: the fact that we are living close to the Madiha.

Yubenibu tanani is the name of our university-longhouse. It means "following the path of those who were transformed into Yube a long time ago". In our longhouse we started to learn. Tanani means to go on learning, in the longhouse. The first ones to teach were dunu, the boa, Dua Busen, our ancestor, uxe, the moon and Yubekã, the beetle diviner.

en en huaiii, en en huaiii, en huaiii na a mae txana muru anua a, anuraãa, anuaaa, anuraãa na a mae txana muru anua a, anurãa, anuaaa, anuraãa
I am arriving, I am arriving, I am arriving From within the village of txana mudu, from there, from there, from there From within the village of txana mudu, from there, from there, from there

\section{Comment:}

Txana means oropendola bird and song leader, Mudu is the name of my father; thus Txana Mudu means the song leader Mudu; the village of Txana Mudu 
is like my father, who is taking care of me, sending me good things. It is a village that sings.

yube bake tuinen txã txã manekin manei,

manekin maneiii

inu bake tuinen txã txã manekin

manei,

manekin maneiii

yubenibu tanani tananibu meranua meranu

meranua meranuu

yubenibu tanani tananibu medanua

medanu,

medanua medanuu

inubun tanani tananibu meranua

meranu

meranua meranuu

duabun tanani tananibu meranua

meranu,

meranua meranuu

inani tanani tananibu meranua

meranu,

meranua meranuu

banubun tanani tananibu meranua

meranu,

meranua meranuu the son of Yube Tuin is blowing the horn txã txã, blowing the horn, blown blowing the horn, blown the son of inu tuin is blowing the horn txã txã, blowing the horn, blown blowing the horn, blown following the path of the people that became yube, inside of the longhouse inside following, inside following following the path of the people that became yube, inside of the longhouse inside following, inside following the people of inu following the path, inside of the longhouse inside following, inside following the people of dua following the path, inside of the longhouse inside following, inside following the people of inani following the path, inside of the longhouse inside following, inside following the people of banu following the path, inside of the longhouse inside following, inside following

\section{Comments of Sebirua:}

Our sons are Tuin, inu bake, of the inu moiety. When they receive visitors they always receive them festively, blowing the armadillo tail horn (yaix hina). I said Yube because this is the song of the vine; those who take a lot of the brew are Yube, all of them together; all this is inside the longhouse of Yube; inside Yube, in his longhouse. The longhouse of Yube taught us: Yube of the moon, 
the boa constrictor/anaconda, the small insect yube. This insect lives in cavities, when you spit on it, it divines: if it raises its arms, the child to be born will be a girl; you put it on the breast of a girl for her breasts to grow quickly; xena sanu: big caterpillar. You take it and ask: "yubekã! Harakidi yuinaka mapuamen?" "yubekã!, where is the game hiding?, where is the person hiding?" It is red, has no feet; it holds its head up. Inside the longhouse one will learn everything.

Yuxãkudu punyawen tsumawe tsumawe tsumawe

Yuxãkudu punyawen tsumawe tsumawe

Basnem Pudu punyawen betãwe, betãwe Basnem Pudu punyawen betãwe, betãwe inani betã betã amawe amawe inani betã betã amawe amawe inani betã betã amawe amawe banu bake betã betã amawe amawe mia xina xabawa xabawe (sh)
The arm of yuxan kudu, the old lady covered in gray, hold it, hold it, hold it (to put medicine in your eye) The arm of yuxan kudu, the old one covered in gray, hold it, hold it, hold it The arm of basnem pudu, lacing, weaving The arm of basnem pudu, lacing, weaving The people of inani, lacing, weaving The people of inani, lacing, weaving The people of inani, lacing, weaving The people of banu, lacing, weaving Clear your toughts

Comment by Sebirua:

The song is asking first the village itself, then the longhouse-university, afterwards yuxan kudu and then basnem pudu: the force I am asking for is for them to clear their vision, of all around them, who are inside, drinking with us, to clear the vision of all of them.

Yuxan kudu and Basnem pudu are mythical figures, the first one is at the origin of medicinal plants that grew out of her burned body, the last one is the ancestor spider woman who taught the women how to spin and weave. She disappeared after the women had offended her. They said she was eating the fresh cotton and substituting it for old fabric, while she was, in fact, industriously spinning the threats out of her body as she was working. When she heard them talking she left forever. 
mia xinã xabawa xabawe

mia xinã kainma a kaima to make your thoughts clear

to bring back your thoughts

\section{Comment:}

When you don't think nor see anything, your thought is caught in a hole, a locked pot; kainma is to bring back your thoughts, rescue you, back to your head, back to your body.

mia xinã kaima kaimaa

kain ini kidãwe kidãwe

kain ini kidãwe kidãwe

xinã kayawamakin kayawa

xinã kayawamakin kayawaa

haux haux, sho sss to make your thoughts flow to make them come out, coming to make them come out, coming guiding the thoughts, guiding guiding the thoughts, guiding haux haux, sho sss

In the sequence we recorded, the next song was a song dedicated to the tobacco snuff to accompany nixi pae. Sebirua explains: "When we inhale dume powder he will make us see, he will shape our thought, he will make us feel nisun. Therefore I have to sing how to take away nisun. When you inhale dume, if you ate game warm, or male game, you will have headache. It's when we inhale dume that we feel this nisun. It's when we take nixi pae that we feel nisun. This song is to take away this feeling."

Nisun is the effect of the revenge of beings that have been killed, of game whose fur has been burned; hunters should avoid the smell. The danger of revenge holds especially for young hunters involved in the killing of male animals. They take revenge through the means of their doubles, their yuxin. Different kinds of game produce nisun. Nisun is dizziness, headache, and when very strong causes fainting. To feel nisun when under the effect of nixi pae and dume is a first step in the discovery of what the yuda baka yuxin, the body spirit of an animal, can do to one's eye soul.

Game animals and humans are dividuals (Strathern, 1988). A duality can become a multiplicity, as happens with the yuda baka, the body soul, which 
gives rise to teeth souls, nail souls, and souls of bodily substances. But basically the body soul acts as a shadow, maintaining the visual characteristics of the living body. The body soul is responsible for a person's capacity to talk. The eye soul, bedu yuxin, on the other hand, resides in the heart and in the eyes and is responsible for perception. From the translation of the songs it appears as if the body soul is responsible for the vocalization, interpretation and reorientation of the eye soul's perceptions and experiences in the world of soul doubles. It is as if the song comes to rescue the eye soul when involved in dangerous aesthetic battles whereby the soul doubles of game throw their clothes, their bodies and their ornaments (that is their body soul) onto the eye soul of the hunter who becomes thus trapped in a new form, a new body in becoming (see Lagrou, 2018). If this process is not counteracted with the right song, the hunter will run off into the forest and slowly, through his new bodily affections and perspective, become transformed in the animal who/which trapped his eye soul with his weapons/ornaments.

The "songs to see" take seriously the risk of becoming what one eats, by the process of being eaten, sexually, by what one has ingested. That is, peccarybecoming, spider-monkey-becoming, these are virtual destinies due to the possibility of inversion of the predatory relation, if revenge is not averted (see Lagrou, 2018). Jaguar-becoming and boa-becoming, on the other hand, are becomings actively sought after by initiating shamans. The ritual is a privileged instance to reveal the logics of an Amerindian ontology in operation. Nixi pae is a mimetic, agonistic and highly aesthetic world in constant process of other-becoming: animal-becoming, women-becoming, child-becoming, plant and vine-becoming and even becoming-molecular. If Deleuze and Guattari (1980) had had the chance to experience this world they might not even have written Mille plateaux any more, deciding that the Huni Kuin had already done so in their songs.

The song traces paths to be followed by the lost eye soul of the suffering person. The eye soul has to follow the design of the song as it unfolds before his eyes to be able to come back, to come close to the body of the one who sings, as well as to come back to his own body. This is the reason why the master of song will lean against the shivering body of the one lost in the world of images, and sing in the plural voice of Yube, that we, I, you miss your body. Song by Leoncio: 


\section{Kayati song of longing for your body}

hatun nai dewedi ee ia ee

nai dewe keneya ee ia ee

yubebaun manekin ee ia ee

manebei danimã ee ia ee ninka ini bidawen ee ia ee

bene yuxin kaiwen ee ia ee yuxin kainkidawen ee ia ee min yuda xinankin ee ia ee yuda xina iniwe ee ia ee

min yuda manukin ee ia ee yuda manu iniwe ee ia ee bake yume buanã ee ia ee

bake yume pae ee ia ee paeyae munuin ee ia ee
Their song from the sky ee ia ee (you are hearing from far away) The song from the sky with design ee ia ee (beautiful; thus you will hear this song and the yuxin leaves in the direction of the song)

We Yube are singing ee ia ee (the vine, yube, that is we, who took the vine, are singing and playing music) singing, honking (blowing) ee ia ee To make him come to listen, to leave ee ia ee (his yuxin listened and is getting better; if not he doesn't leave from the vine, stays there enmeshed) For the person's yuxin to arrive ee ia ee For the person's yuxin to leave quickly ee ia ee Thinking of your body ee ia ee Thinking of your body to go up and join me ee ia ee (I will get there, the person will lean on the body of the person who is singing and, singing slowly, he will get better)

I long for (miss) your body ee ia ee Longing for the body, move up this way ee ia ee The grown up one is drunk ee ia ee (and thus longs for (misses) the body of the one who is singing the vine song)

The grown up one is drunk ee ia ee Dancing with the drunken vine ee ia ee

The vine connects the people by means of the song. It is in you who know; (you) know where he goes, he knows that you know, because he has already swallowed you. (It is he who is singing in you with you). Goes to the other, it can be that (this one) is afraid. The path of the vine is also to walk between people. If I know how to sing, everybody will feel the way I sing. If the vine is my friend or my wife, I won't feel the effect strongly, but the other will scream. (Sebirua, 2015). 
Leoncio explains that what we say in song is not what we see, that these are the technical names, in the twisted language of the vine, as Townsley (1993) would say. In vine language you never call the animal spirit or his owner by his everyday name. ${ }^{26}$ But what we see is an imagistic description of what these doubles are doing to the person. The eye soul lost in a world of image-beings became trapped and the song, a song with a complex enunciator, being both we, he and you, is coming to its rescue. The eye soul himself doesn't sing. Thus the one who sings is the interpreter while the other is having the perceptions. This dual model of two souls, one having the perceptions, the other interpreting them, reminds us of the homunculo model of cognition described by Dennett and cited by Gell (1998). Huni Kuin ontology, as it unfolds through the analysis of the huni ritual, professes a theory of fractal personhood, where every unity is dual and every duality is a movement in-between. The ritual consists in exploring to the limit the lines of flight of this constant process of other-becoming.

To be devoured by Yube in his monstrous, frightening form of not human nor animal, but some undefined being in-between, is at the same time longed for and terribly feared. This is the test the strong hearted have to pass in their adventure of other-becoming. Actually it is the path to initiation in the art of singing and thus mastering the experience with nixi pae. To sing with the power of the vine in your voice, you have to engage in a process of becoming that only the song can trace and undo.

Yubebaun manikin ee ia ee, means: We, yubebaun are playing. Yube is we; we are taking the vine in the company of Yube. Yubebun means a lot of them (a multiplicity), we singing. Singing together with Yube you have to warn (avisar) Yube to take away the headache, to warn, we sing all the illness we have: I have a lot of illnesses, headache, my knee, my back, fainting; we eat deer, fish, crab, spider monkey, male peccary. All these are names. Yubebun is us singing. (Leôncio, 2007).

Several songs express the process and the fear of being killed, swallowed, clubbed down, cut into pieces, encircled by Yube. We give an extract as example:

26 See Déléage (2009) for the translation and analysis of Sharanahua ayahuasca songs that display a logic close to, but also interestingly different from, that of the Huni Kuin 


\section{One of the songs to call Yube}

mia yuda kuwa eenkiki eenkiki ee ikeãtã bani eenkiki eenkiki ee sidikime bainun eenkiki eenkiki ee eenkiki eenkiki ee haa haa eenkiki eenkiki ee meteseme bainun eenkiki eenkiki ee xawakame bainun eenkiki eenkiki ee paexawakamenun eenkiki eenkiki ee xawakame bainun een kiki een kiki hawen xawã hinaya eenkiki eenkiki ee ikeãtã baini een kiki een kiki pae buakaya eenkiki eenkiki ee xinan kainkidawen eenkiki eenkiki ee Haa Haa een kiki een kiki bake yume paein eenkiki eenkiki ee mia paen datea eenkiki eenkiki ee paen datebaini eenkiki eenkiki ee ikeãtã baini eenkiki eenkiki ee Haa Haa eenkiki eenkiki ee eenkiki eenkiki ee een kiki een kiki ee hauxhaux

\author{
warming up your body \\ they almost finished encircling, already \\ it is not there anymore, it is already \\ coming down \\ coming down in pieces \\ a liquid is flowing from your body \\ the force like a liquid flowing from \\ your body \\ a liquid is flowing from your body \\ with his macaw tail \\ they almost finished encircling, already \\ the force has already been taken away \\ slowly bringing back your thought eenkiki \\ eenkiki ee \\ the grown up child is drunk eenkiki \\ eenkiki ee \\ the force frightened you eenkiki \\ eenkiki ee \\ the fear of the force is ebbing away eenkiki \\ eenkiki ee \\ they almost finished encircling, already \\ haux haux
}

\section{Comment by Leoncio:}

Macaw tail refers to the seeing of blood on the body. Here it is already flowing down. The person will be afraid because can be seeing himself dying. This is Yube. The "grown up child" is the word for "person" in vine language, it means the person under the pressure of the vine. This song is to call a very strong force; to call Yube. Hawen pae uinmakin: To make see his power, his drunkenness. 
The song makes use of onomatopoeias, personifying the terrifying voice of Yube. To be swallowed by Yube is necessary to be reborn as Yube. The bloody scene of being a victim of Yube is yet another instance of inversion of the position of prey and predator, since one has to swallow Yube's blood, the brew, to become visible for him, to be looked at and thus become a candidate prey. Only those who have had the experience of having been eaten and thrown up by Yube have become one with him and have the power to make visions come through song. After this experience one will decide whether to continue or not with the science of Yube. Leoncio has been swallowed, and is strong. He also encountered the boa's yuxin in the forest and asked him for his knowledge.

The relation between man and woman with its possible inversions of position between prey and predator is also central to nixi pae visionary experience, as we saw in the founding myth. Several healing songs invoke the mythical encounter between tapir, known for his sexual appetite and big virile member, and the irresistible snake woman. The sexual act appears in images of eating and being eaten. When her poor human husband Busen is in panic during his first experience with the brew, Yube ainbu, Yube as woman, his wife, sings a song for him: The song of the female anaconda chewing on the intestines of her lover the tapir.

The vision of Yube arriving is the starting point of all kinds of other processes of transformation involving the person who is having the vision. And one needs not be devoured by Yube to experience this:

When you see the snake that is going to swallow you, this means he is going to put you in the root of the vine. You are going to be sitting in the root of the vine. The vine transformed itself. Now he has already shown this to you. Actually he is going to show you. This is true as follows. When I took the vine when I was young, I was transformed. My body became the vine, but in fact what happened was that he (Yube) had showed me how he became (a vine). (Sebirua, 2015).

Txana: "From my neck sprouted a vine that became a big tree."

Sebirua: "I thought I had really become a vine, you will feel it yourself in vision. But my heart was still beating." (Sebirua, 2015). 
The heart still beating, while the eye soul is wrapped up by the agency of other image-beings, points at yet another aspect of in-betweenness or doubling. The eye soul, which is considered the real soul, realizes it/he/she has not yet died or not yet totally become other because it/he/she feels the heart still beating.

\section{References}

AQUINO, T.; IGLESIAS, M. P. Kaxinawá do rio Jordão: história, território, economia e desenvolvimento sustentado. Rio Branco: Comissão Pró-Índio do Acre, 1994.

BELAUNDE, L. E. Diseños materiales e inmateriales: la patrimonialización del kene y de la ayahuasca en el Perú. Mundo Amazônico, n. 3, p. 123-146, 2012.

BELAUNDE, L. E. Donos e pintores: plantas e figuração na Amazônia Peruana. Mana, Rio de Janeiro, v. 22, n. 3, p. 611-640, 2016.

CALAVIA, O. O nome e o tempo dos Yaminawa. São Paulo: Unesp, 2006.

CARNEIRO DA CUNHA, M. Cultura com aspas: e outros ensaios. São Paulo: Cosac Naify, 2009.

CASTOR, D. C. Xinã bena, dinâmicas de um novo tempo: desenvolvimento e cultura entre os Kaxianawa do rio Jordão. 2012. Dissertação (Mestrado em Psicossociologia de Comunidades e Ecologia Social)-Centro de Filosofia e Ciências Humanas, Universidade Federal do Rio de Janeiro, Rio de Janeiro, 2012.

CESARINO, P. Oniska: poética do xamanismo na Amazônia. São Paulo: Perspectiva: Fapesp, 2011.

CHAUMEIL, J.-P. Réseaux chamaniques contemporaines et relations interethniques dans le haut Amazone (Pérou). In: PINZÓN, C.; SUÁREZ, R.; GARAY, G. (Ed.). Otra América en construcción. Bogotá: ICAN, 1991. p. 9-21.

COLPRON, A.-M. Dichotomies sexualles dans l'étude du chamanisme: le contre-exemple des femmes "chamanes" Shipibo-conibo (Amazonie péruvienne). 2004. Thesis (PhD)-Université de Montréal, Montréal, 2004.

CONKLIN, B. Shamans versus pirates in the Amazonian treasure chest. American Anthropologist, v. 104, n. 4, p. 1050-1061, 2002.

COUTINHO, T. Forest shamanism in the city: the Kaxinawá example. Sociologia e Antropologia, Rio de Janeiro, v. 6, n. 1, p. 159-179, 2016. 
DÉLÉAGE, P. Le chant de l'anaconda: l'apprentissage du chamanisme chez les Sharanahua (Amazonie occidentale). Nanterre: Société d'Ethnologie, 2009.

DELEUZE, G.; GUATTARI, F. Mille plateaux. Paris: Minuit, 1980.

DESHAYES, P. Les trois mondes du Santo Daime. Socio-Anthropologie, n. 17-18, p. 61-83, 2006.

GALLOIS, D. Donos, detentores e usuários da arte gráfica kusiwa. Revista de Antropologia, São Paulo, v. 55, n. 1, p. 20-49, 2012.

GEBHART-SAYER, A. Una terapia estética: los diseños visionarios del ayahuasca entre los Shipibo-Conibo. América Indígena, v. 46, n. 1, p. 189-218, 1986.

GELL, A. Art and agency: an anthropological theory. Oxford: Clarendon Press, 1998.

GIL, L. P. Metamorfoses yaminawa: xamanismo e socialidade na Amazônia peruana. 2006. Tese (Doutorado em Antropologia Social)-Centro de Filosofia e Ciências Humanas, Universidade Federal de Santa Catarina, Florianópolis, 2006.

GOLDSTEIN, I.; LABATE, B. Encontros artísticos e ayahuasqueiros: reflexes sobre a colaboração entre Ernesto Neto e os Huni Kuin. Mana, Rio de Janeiro, v. 23, n. 3, p. 437-471, 2017.

GOW, P. River people: shamanism and history in Western Amazonia. In: THOMAS, N.; HUMPHREY, C. (Ed.). Shamanism, history, and the state. Ann Arbor: University of Michigan Press, 1994. p. 90-113.

GOW, P. An Amazonian myth and its history. Oxford: Oxford University Press, 2001.

IBÃ, I. S. I. K. Nixi pae, o espírito da floresta. Rio Branco: Comissão Pró-Índio do Acre, 2006.

ILLIUS, B. Ani Shinan: Shamanismus bei den Shipibo-Conibo (Ost-Peru). Tübingen: Verlag S\&F, 1987.

KEIFENHEIM, B. Concepts of perception, visual practice, and pattern art among the Cashinahua Indians (Peruvian Amazon area). Visual Anthropology, v. 12, n. 1, p. 27-48, 1999.

KEIFENHEIM, B. Nixi Pae como participação sensível no princípio de transformação da criação primordial entre os índios Kaxinawá no Leste do Peru. In: LABATE, B. C.; ARAÚJO, W. S. (Org.). O uso ritual da ayahuasca. Campinas: Mercado de Letras: Fapesp, 2002. p. 95-125.

KENE YUXI, AS VOLTAS DO KENE. Director, director of photography: Zezinho Yube. Producer: Vídeo nas Aldeias. 2010. $48 \mathrm{~min}$, color.

KENSINGER, K. How real people ought to live: the Cashinahua of Eastern Peru. Prospect Heights: Waveland Press, 1995. 
LABATE, B. C.; CAVNAR, C.; GEARIN, A. K. (Ed.). The world ayahuasca diaspora: reinventions and controversies. Abingdon: Routledge, 2017.

LABATE, B. C.; ROSE, I. S. de; SANTOS, R. G. dos. (Ed.). Ayahuasca religions: a comprehensive bibliography and critical essays. Santa Cruz: MAPS, 2009.

LAGROU, E. A fluidez da forma: arte, alteridade e agência em uma sociedade amazônica (Kaxinawa, Acre). Rio de Janeiro: Topbooks, 2007.

LAGROU, E. Le graphisme sur les corps amérindins. Des Chimères abstraites?. Gradhiva: Revue d'anthropologie et d'histoire des arts, Paris, n. 13, p. 68-93, 2011.

LAGROU, E. Podem os grafismos ameríndios ser considerados quimeras abstratas? Uma reflexão sobre uma arte perspectivista. In: SEVERI, C.; LAGROU, E. (Org.). Quimeras em diálogo: grafismo e figuração nas artes indígenas. Rio de Janeiro: 7Letras, 2013a. p. 67-109.

LAGROU, E. Controlar la fluidez de la forma: la sanación con el uso del nixi pae entre los Cashinahua. In: LABATE, B. C.; BOUSO, J. C. (Ed.). Ayahuasca y salud. Barcelona: Los Libros de la Liebre de Marzo, 2013b. p. 120-142.

LAGROU, E. Copernicus in the Amazon: ontological turnings from the perspective of Amerindian ethnologies. Sociologia e Antropologia, Rio de Janeiro, v. 8, n. 1, p. 133-167, 2018.

LANGDON, E. J. Interethnic processes affecting the survival of shamans. A comparative analysis. In: PINZÓN, C.; SUÁREZ, R.; GARAY, G. (Ed.). Otra América en construcción. Bogotá: ICAN, 1991. p. 44-65.

LANGDON, E. J. Redes xamânicas, curanderismo e processos interétnicos: uma análise comparativa. Mediações, Londrina, v. 17, n. 1, p. 62-82, 2012.

LANGDON, E. J.; ROSE, I. S. de. Diálogos (neo)xamânicos: encontros entre os Guarani e a ayahuasca. Tellus, Campo Grande, v. 10, n. 18, p. 83-113, 2010.

LOSONCZY, A.-M.; MESTURINI, S. Entre l'“Occidental” et l'“Indien”. Ethnographie des routes du chamanisme ayahuasquero entre Europe et Amériques. Autrepart, v. 56, n. 4, p. 93-110, 2010.

LUNA, L. E. Vegetalismo: shamanism among the mestizo population of the Peruvian Amazon. 1986. Thesis (Ph.D Comparative Religion)-University of Stockholm, Stockholm, 1986.

MANDUCA, A. M. I. M. (Org.). Una hiwea. Belo Horizonte: Faculdade de Letras UFMG, 2012.

MANDUCA, A. M. I. M.; QUINET, A. Una Isĩ Kayawa: o livro da cura do povo huni kuĩ do rio Jordão. Rio de Janeiro: Dantes, 2014

MATTOS, A. P. de; IBÃ, H. K. Why MAHKU - movimento dos artistas huni kuin sing?. GIS, São Paulo, v. 2, n. 1, p. 61-82, 2017. 
MCCALLUM, C. Gender and sociality in Amazonia: how real real people are made. Oxford: Berg, 2002.

MONTAG, R. A tale of Pudicho's People: the Cashinahua narrative accounts of European contact in the 20th century. Dallas: SIL, 2002. (International Museum of Cultures Publications in Ethnography, no. 38).

NETO, E. Haux haux. Catalogue Arp Museum Bahnhof Rolandseck. Köln, 2014.

REIS, R. Arte, corpo e criação: vibrações de um modo de ser yawanawa. 2015. Dissertação (Mestrado em Sociologia e Antropologia)-Instituto de Filosofia e Ciências Sociais, Universidade Federal do Rio de Janeiro, Rio de Janeiro, 2015.

ROE, P. The cosmic zygote: cosmology in the Amazon basin. Rutgers: The Sate University of New Jersey, 1982.

SILVA, M. Povos indígenas e Estado. A experiência do Acre. In: BARROSO HOFFMANN, M.; SOUZA LIMA, A. C. (Org.). Estado e povos indígenas: bases para uma nova política indigenista II. Rio de Janeiro: Contra Capa Livraria, 2002. p. 25-30.

STENGERS, I. Cosmopolitiques I: la guerre des sciences. Paris: La Découverte, 1997.

STRATHERN, M. The gender of the gift. Berkeley: University of California Press, 1988.

SZTUTMAN, R. O profeta e o principal. São Paulo: Edusp, 2012.

TAUSSIG, M. Shamanism, colonialism and the wild man: a study in terror and healing. Chicago: University of Chicago Press, 1986.

TAUSSIG, M. Mimesis and alterity: a particular history of the senses. New York: Routledge, 1993.

TAUSSIG, M. I swear I saw this: drawings in fieldwork notebooks, namely of my own. Chicago: University of Chicago Press, 2011.

TAUSSIG, M. The corn wolf. Chicago: University of Chicago Press, 2015.

TOWNSLEY, G. Song paths. The ways and means of Yaminahua shamanic knowledge. L'Homme, v. 33, n. 126-128, p. 449-468, 1993.

VIVEIROS DE CASTRO, E. Perspectival anthropology and the method of controlled equivocation. Tipití, San Antonio, v. 2, n. 1, p. 3-22, 2004.

Recebido: 31/05/2017 Aceito: 14/03/2018 | Received:5/31/2017 Accepted:3/14/2018 